\title{
An in vitro analysis of the total phenolic content, antioxidant power, physical, physicochemical, and chemical composition of Terminalia Catappa Linn fruits
}

\author{
Composição física, físico-química, química, análise do teor de fenólicos totais e poder antioxidante in vitro de
} frutos de Castanhola (Terminalia Catappa Linn)

\section{Marcelo Rodrigues MARQUES ${ }^{1}$, Diego Damasceno PAZ1, Lívia Patrícia Rodrigues BATISTA ${ }^{1}$, Celma de Oliveira BARBOSA ${ }^{1}$, Marcos Antônio Mota ARAÚJO ${ }^{1}$, Regilda Saraiva dos Reis MOREIRA-ARAÚJO ${ }^{1 *}$}

\begin{abstract}
This study assessed the antioxidant, total phenolic, and physicochemical properties of in vitro Terminalia Catappa Linn (locally called castanhola) using the DPPH assay. The castanhola fruits had an average weight of $19.60 \pm 0.00 \mathrm{~g}$, combining shell, pulp, and seed weight, and a soluble solids content of $8^{\circ} \mathrm{Brix}$. The chemical composition was determined with predominance of carbohydrates (76,88 $\left.\pm 0,58 \%\right)$. The titration method was used to determine Vitamin C content using 2,6-dichlorophenolindophenol (DCFI), known as reactive Tillmans resulting in no significant levels. Aqueous extracts of castanhola pulp showed a higher concentration of phenolics, $244.33 \pm 18.86$ GAE. $\mathrm{g}^{-1}$ of fruit, and alcoholic extracts, $142.84 \pm 2.09 \mathrm{GAE} \cdot \mathrm{g}^{-1}$ of fruit. $\mathrm{EC}_{50}$ values of the aqueous extract showed a greater ability to scavenge free radicals than the alcoholic extracts. The fruit had a significant content of phenolic compounds and high antioxidant capacity.

Keywords: tropical fruit; functional properties; bioactive compounds.
\end{abstract}

\begin{abstract}
Resumo
Este estudo teve como objetivo determinar as características físicas, físico-químicas e químicas, teor de fenólicos totais e poder antioxidante da castanhola (Terminalia Catappa Linn) in vitro, por meio de descolorimento de radical DPPH (2,2-difenill-1-picrihidrazil). O fruto da castanhola apresentou peso médio de 19,60 \pm 0,00 g, quando somados os pesos da polpa, casca e semente e um teor de sólidos solúveis de $8^{\circ}$ Brix. Determinou-se a composição química, obtendo-se uma predominância de carboidratos( $\left.76,88 \pm 0,58 \%\right)$.A quantificação da Vitamina C foi feita segundo o método titulométrico, usando-se o reagente 2,6-diclorofenolindofenol (DCFI), conhecido como reativo de Tillmans, obtendo-se teores não significativos. Os extratos aquosos da polpa da castanhola apresentaram uma concentração maior de fenólicos totais, com resultados de 244,33 $\pm 18,86$ GAE.g ${ }^{-1}$ do fruto e os extratos alcoólicos umteor de 142,84 $\pm 2,09$ GAE.g $^{-1}$ do fruto. Os valores de EC dos $_{50}$ extratos aquosos apontaram uma maior capacidade de sequestrar radicais livres do que dos extratos alcoólicos. O fruto tem um conteúdo significativo de compostos fenólicos e elevada capacidade antioxidante.

Palavras-chave: fruto tropical; caracteríticas funcionais; compostos bioativos.
\end{abstract}

\section{Introduction}

The Terminalia Catappa Linn tree is known as castanheira, castanhola, castanholeira, chapéu-de-sol e sete-copas, belongs to the Combretaceae family. Its trunk can be straight or tortuous and ranges from 25 to $45 \mathrm{~m}$ in height and 50 to $150 \mathrm{~cm}$ in diameter. Originally from South Asia (specifically India, Malaysia, Philippines, and Indonesia), it was introduced to Brazil for ornamental purposes in urban and rural afforestation and reforestation (CAVALCANTE et al., 1986; GILMAN; WATSON, 1994; OLIVEIRA et al., 2000; ANGEL et al., 2003; THOMSON; EVANS, 2006).

The fruits are popularly called almonds or Indian almonds. They are edible and are used in food, especially for children, birds, and other animals. In addition to the pulp, the nut inside the seed is also edible - a source of proteins and lipids
(CAVALCANTE et al., 1986; MATOS et al., 1992; IVANI et al., 2008).

Many species of the genus Terminalia have been used for medicinal purposes in Asian countries and to treat infectious diseases in western Africa (OLIVEIRA et al., 2000; SOUSA et al., 2007).

Currently, several studies show that free radicals and other oxidants play a key role in the development of diseases that are related to premature aging and chronic non-communicable diseases (ATOUI et al., 2005; SOUSA et al., 2007).

Driven by concerns about their future health and the daily benefits that a correct diet can offer, Brazilians have been seeking healthy foods, especially foods that are

\footnotetext{
Received 26/10/2010

Accepted 8/12/2011 (005111)

${ }^{1}$ Department of Nutrition, Federal University of Piauí - UFPI, Campus Ministro Petrônio Portela, s/n, Bloco 13, Bairro Ininga, CEP 64049-550, Teresina, PI, Brazil,

e-mail: regilda@ufpi.edu.br; m_marcelorodrigues@hotmail.com

${ }^{*}$ Corresponding author
}

DOI: http://dx.doi.org/10.1590/S0101-20612012005000023 
inexpensive and can be supplied locally (SANTOS, 2007). Phenolic compounds are aromatic compounds that result from the secondary metabolism of plants (KIM; JEONG; LEE, 2003). They have an adaptive-protective role, and their importance has been shown in numerous studies, particularly the importance of flavonoids, anthocyanins, and anthoxanthins, which proves the ability to capture free radicals and thus promote the prevention of cardiovascular and circulatory diseases, cancer, diabetes, and Alzheimer's disease (ISHIGE; SCHUBERT; SAGARA, 2001; WANG; MAZZA, 2002; STOCLET et al., 2004; ABDILLE et al., 2005; KHATOON et al., 2008).

The bark of plants of the genus Terminalia is a source of terpenoids, flavones, and phenolic compounds, and the presence of tannins in the peel of the fruits is a characteristic of this genus (KHATOON et al., 2008).

The aim of this study was to determine the physicochemical composition of castanhola fruits (Terminalia Catappa Linn) and also to quantify their total phenolics and antioxidant capacity.

\section{Material and methods}

\subsection{Raw material}

Twenty mature fruits were randomly selected from trees at the Ininga campus of the Federal University of Piauí-UFPI.

Once selected, the fruits were rinsed in water and measured. They were then peeled manually with the aid of stainless steel knives to separate the pulp, which was homogenized for subsequent analysis of chemical, total phenolic, and antioxidant properties.

\subsection{Physical parameters}

The following measurements of physical variables were performed in the 20 randomly selected fruits: the average dimensions of the fruits (using Mitutoyo callipers) and the weight of the whole fruit, peel, core, and the pulp to obtain a final average weight using a digital weighing scale (MARTE model AY220). These data were used to calculate the ratio among shell, core, and pulp. The $\mathrm{pH}$ was measured using a $\mathrm{pH}$ meter (WTW model $\mathrm{pH} 330 \mathrm{i} / \mathrm{SET}$ ) and calibrated with $\mathrm{pH} 4.0$ buffer solution. The soluble solids were determined using a refractometer (QUIMIS model Q767A1).

\subsection{Chemical measurements of the pulp}

The measurement of moisture and ash content were calculated using the method described by Association of Official Analytical Chemists (2000). The ether extract was measured using the method recommended by the Institute Adolfo Lutz (2008). Fatty matter was extracted from the sample with hexane using a Soxhlet extractor. The protein content was determined according to the Association of Official Analytical Chemists (2000) method and included evaluation of total nitrogen following the method of Kjedahl. The quantity of protein was calculated by multiplying the total nitrogen content of the sample by 6.25 .
The carbohydrate content was determined by subtracting values of protein, fat, ash, and moisture from 100 according to the analytical standards of the Institute Adolfo Lutz (2008). The titration method was used to determine Vitamin C content using 2,6-dichlorophenolindophenol (DCFI), known as reactive Tillmans.

\subsection{Obtaining extracts and chemicals and standards}

The sample was previously dried in a ventilated oven at $50^{\circ} \mathrm{C}$. After grinding, $5 \mathrm{~g}$ of the sample was used in the sequential extraction using ethyl ether (PROQUIMIOS ${ }^{\circ}$ ), ethanol (VETEC ${ }^{\circledR}$ ), and distilled water. The residues were filtered using Whatman $\mathrm{N}^{\circ} 4$ filter paper according to the method described by Larrauri, Rupérez and Saura-Calixto (1997), adapted by Lima (2008).

The study used SIGMA ${ }^{\star}$ brand reagents and standards (such as the DPPH). Folin Denis Reagent was purchased from DINAMICA $^{\circ}$, and the sodium carbonate, Gallic acid, and methanol were supplied by VETEC.

\subsection{Determination of total phenolic compounds in the extracts}

The quantification of total phenolics was measured using Folin's reagent (SWAIN; HILLIS, 1959, adapted by LIMA, 2008). A calibration curve was created with different solutions of gallic acid, and the results were expressed as mg GAE (gallic acid equivalent).The reading at $720 \mathrm{~nm}$ in a CELM spectrophotometer was achieved by transferring $0.5 \mathrm{~mL}$ of the solution of the extracts of the fruit to a $10 \mathrm{~mL}$ container and by adding $0.5 \mathrm{~mL}$ of Folin Denis reagent. The solution was homogenized, allowed to stand for 3 minutes, and then $1 \mathrm{~mL}$ of saturated solution of sodium carbonate $\left(\mathrm{NaCO}_{3}\right)$ was added. The final volume was completed with distilled water.

\subsection{Evaluation of antioxidant activity of the extracts $D P P H$ radical method}

In this study, the antioxidant activity was assessed in terms of hydrogen-donating or radical scavenging ability of extracts. A methanolic solution $(1 \mathrm{~mL})$ of the extract at four different concentrations was added to $3 \mathrm{~mL}$ of DPPH solution $\left(6 \cdot 10^{5} \mathrm{M}\right.$ in methanol). The decrease in the absorbance at $517 \mathrm{~nm}$ was measured using a CELM spectrophotometer until the reaction reached the steady state in the dark (BRAND-WILIAMS; CUVELIER; BERSET, 1995). Radical scavenging activity was expressed as the inhibition percentage and was calculated as follows (Equation 1):

$\%$ Protection $=($ Abs control - Abs sample $) \times 100 /$ Abs control

The present study also assessed the kinetic parameters of the capture reaction of the DPPH radical at four different times: 5, 10, 15, and 20 minutes of reaction (SÁNCHEZ-MORENO; LARRAURI; SAURA-CALIXTO, 1998).

\section{Results and discussion}

\subsection{Physical and physicochemical characteristics}

Since this is not a commercial fruit, the data about the physical and physicochemical properties of castanholas are not 
easily found in the literature. Table 1 shows the comparative data of physical parameters found in this study and the study of Cavalcante (1986).

The analysis of the data shows that there was a difference in the average weight of whole fruit $(19.60 \pm 0.00 \mathrm{~g})$ and the average weight of the seed $(7.28 \pm 0.59 \mathrm{~g})$ when compared with Cavalcante's data (1986), who obtained an average weight of whole fruit of $38.37 \pm 0.00 \mathrm{~g}$ and average weight of seed of $20.23 \pm 0.00 \mathrm{~g}$ (Table 1). However, higher pulp yield $(57.34 \%)$ was obtained even with lower average weights. The dimensions of the fruit showed similar results, which shows that the differences may be caused by differences in location, planting techniques, and soil type. Nevertheless, the fruits maintain a certain regularity of physical characteristics.

The ${ }^{\circ}$ Brix and vitamin $\mathrm{C}$ values could not be compared because there are no studies in the literature that address these aspects of castanhola fruits.

Analysis of the nutritional composition of the fruit shows that there is a high quantity of carbohydrates and water in its composition (Table 2). The consumption of $100 \mathrm{~g}$ of castanhola supplies $17.09 \%$ of the caloric needs of an adult based on a diet of $2.000 \mathrm{kcal}$.

The reduced levels of vitamin $\mathrm{C}$ in the castanhola fruits is mainly due to the high rainfall in the region during the harvest period, which probably diluted both the soluble solids and the ascorbic acid present in the cellular juice of the fruit, as revealed by the level of humidity found in the composition of the fruit.

\subsection{Quantification of in vitro total phenolics and antioxidant capacity}

This study assessed the total phenolic content of aqueous and alcoholic extracts of castanhola, and the results are presented in Table 3. According to the data, the two extracts that were examined had significant quantities of phenolic compounds.

A comparison of the efficiency of solvent extraction, in Table 3, shows that pure water had a higher power to extract phenolic compounds present in the castanhola when compared with the alcoholic solution. This demonstrates that the majority of the phenolic compounds of these castanholas have a higher polarity and are therefore more hydrosoluble.

Recent research has shown that phenolic compounds, in addition to playing a role in the capture of free radicals, may also be involved in other physiological mechanisms that stimulate the activity of antioxidant enzymes or as cellular signaling substances that activate and/or inhibit the expression of some enzymes related to the cancer process (KATSUBE et al., 2003, SHAHIDI; ALASALVAR; LIYANA-PATHIRANA, 2007). Therefore, studies that quantify these compounds in foods are of vital importance.

According to Nagappa et al. (2003), the presence of phenolic compounds indicates that the fruit has the potential to prevent and possibly treat certain diseases. In this regard, extracts from the castanhola fruits (Terminallia C. Linn) were described as being anti-hypoglycemiants and capable of regenerating $\beta$-cells in the pancreas.
Table 1. Physical and physicochemical parameters of castanholas in different studies. Teresina-PI, 2010.

\begin{tabular}{lcc}
\hline \multicolumn{1}{c}{ Parameters } & $\begin{array}{c}\text { Values } \\
\text { obtained }\end{array}$ & $\begin{array}{c}\text { Values obtained by } \\
\text { Cavalcante (1986) }\end{array}$ \\
\hline Number of fruits & 20 & 86 \\
Average weight of fruits $(\mathrm{g})$ & $19.60 \pm 0.00$ & $38.37 \pm 0.00$ \\
Pulp (g) & $11.24 \pm 2.35$ & $13.72 \pm 0.00$ \\
Shell $(\mathrm{g})$ & $1.08 \pm 0.00$ & $2.32 \pm 0.00$ \\
Seed $(\mathrm{g})$ & $7.28 \pm 0.59$ & $20.23 \pm 0.00$ \\
Pulp yield (\%) & 57.34 & 35.80 \\
Shell percentage & 5.51 & 6.20 \\
Seed percentage & 37.14 & 52.50 \\
Length/ Height $(\mathrm{cm})$ & $4.32 \pm 0.00$ & $4.11 \pm 0.00$ \\
Width $(\mathrm{cm})$ & $3.16 \pm 0.00$ & $3.42 \pm 0.00$ \\
Thickness $(\mathrm{cm})$ & $2.57 \pm 0.00$ & - \\
Soluble solids $\left({ }^{\circ}\right.$ Brix $)$ & $8 \pm 0.00$ & - \\
\hline
\end{tabular}

Table 2. Chemical composition of Castanhola fruits. Teresina-PI, 2010.

\begin{tabular}{lc}
\hline \multicolumn{1}{c}{ Nutrients } & $\begin{array}{c}\text { Castanhola } \\
(\text { mean } \pm \text { SD) }\end{array}$ \\
\hline Humidity (\%) & $17.2 \pm 1.13$ \\
Ash (\%) & $0.83 \pm 0.24$ \\
Lipids (\%) & $2.79 \pm 0.58$ \\
Proteins (\%) & $2.30 \pm 0.00$ \\
Carbohydrates (\%) & $76.88 \pm 0.58$ \\
Vitamin C content (mg.100 g $\left.{ }^{-1}\right)$ & $0.22 \pm 0.00$ \\
Total Energetc Value (TEV) $\left(\mathrm{kcal}^{\circ} 100 \mathrm{~g} \mathrm{~g}^{-1}\right)$ & 341.83 \\
\hline
\end{tabular}

Table 3. Content of total phenolic compounds in castanhola fruits. Teresina-PI, 2010.

\begin{tabular}{ccc}
\hline Fruit & \multicolumn{2}{c}{$\begin{array}{c}\text { Extraction }\left(\mathrm{mg} \mathrm{GAE} \cdot \mathrm{g}^{-1} \text { of fruit }\right) \\
\text { alcoholic aqueous }\end{array}$} \\
\cline { 2 - 3 } & $($ Mean $\pm \mathrm{SD})$ & $($ Mean $\pm \mathrm{SD})$ \\
\hline Castanhola $\left(\mathrm{mg}^{\left.100 \mathrm{~g}^{-1}\right)}\right.$ & $142.84 \pm 2.09$ & $244.33 \pm 18.86$ \\
\hline
\end{tabular}

These functions of phenolic phytochemicals are due to their ability to efficiently scavenge radicals. Studies of tea have found a maximum quantity of $50 \mathrm{mg} \mathrm{GAE} . \mathrm{g}^{-1}$. When comparing phenolic quantifications in the cashew fruit, it was found that the castanhola has a higher composition of these compounds compared to that of the cashew pseudo-fruit with 2.8 to $10.4 \mathrm{mg}$ of gallic acid/g of bagasse (ASOLINI; TEDESCO; CARPES, 2006; BROINIZI et al., 2007; SOARES et al., 2008).

The quantity measured in this study is comparable to the phenolic content found in $100 \mathrm{~g}$ the Niagara and Isabella varieties of grape, $183.04 \pm 11.63$ and $196.83 \pm 16.97 \mathrm{mg} \mathrm{GAE}$, respectively, which are widely recognised as potential sources of phenolic compounds (ASOLINI; TEDESCO; CARPES, 2006; BROINIZI et al., 2007; SOARES et al., 2008).

The DPPH method is one of the most widely used chemical methods to determine antioxidant capacity because it is considered to be practical, fast, and stable (SOARES et al., 2008). 
Table 4. Percentage of inhibition of the DPPH radical by castanhola extracts, after 20 minutes. Teresina-PI, 2010.

\begin{tabular}{cccccc}
\hline Extracts & \multicolumn{4}{c}{ Concentrations $\left(\mu \mathrm{g} \cdot \mathrm{mL}^{-1}\right)$} & $\mathrm{EC}_{50}$ \\
\cline { 2 - 5 } & 12.5 & 25 & 50 & 100 & $\left(\mu \mathrm{g} \cdot \mathrm{mL}^{-1}\right)$ \\
\hline Aqueous (\%) & 50.00 & 57.73 & 61.81 & 71.09 & 0.70 \\
& $( \pm 0.00)$ & $( \pm 2.72)$ & $( \pm 3.44)$ & $( \pm 4.33)$ & \\
Alcoholic $(\%)$ & 33.67 & 34.44 & 46.94 & 51.36 & 85.99 \\
& $( \pm 0.00)$ & $( \pm 0.61)$ & $( \pm 1.11)$ & $( \pm 5.31)$ & \\
\hline
\end{tabular}

The antioxidant activity of the aqueous and alcoholic extracts of the castanhola fruits obtained using the DPPH radical scaveging method is shown in Table 4 . The results were expressed as $\mathrm{EC}_{50}$ (the quantity of antioxidant in the extracts that is capable of reacting with $50 \%$ of the radical in the DPPH solution). Therefore, the lower the $\mathrm{EC}_{50}$ value, the greater the antioxidant activity of the extract analyzed.

There is a higher antioxidant activity in the aqueous extract with $\mathrm{EC}_{50}$ values of $0.70 \mu \mathrm{g} \cdot \mathrm{mL}^{-1}$, which also had a higher concentration of phenolic compounds. In this case, the concentration of these compounds was directly related to the antioxidant activity.

Compared with Brazilian cerrado fruits, extracts of the castanhola are more effective antioxidants. Roesler et al. (2007), in their study on pequi, araticum, cagaita, and lobeira pulps obtained $\mathrm{EC}_{50}$ values in alcoholic extracts of $298.75 \pm 3.80 \mu \mathrm{g} . \mathrm{mL}^{-1}, 148.82 \pm 0.98 \mathrm{mg} \cdot \mathrm{mL}^{-1}$, $387.47 \pm 8.70 \mathrm{mg} \cdot \mathrm{mL}^{-1}$ and $162.97 \pm 2.05 \mu \mathrm{g} \cdot \mathrm{mL}^{-1}$, respectively. In aqueous extracts, the results were respectively $534.43 \pm 7.32 \mu \mathrm{g} . \mathrm{mL}^{-1}, 198.28 \pm 8.24 \mu \mathrm{g} . \mathrm{mL}^{-1}, 879.33 \pm 11.70 \mu \mathrm{g} \cdot \mathrm{mL}^{-1}$, and $1328.98 \pm 9.42 \mu \mathrm{g} \cdot \mathrm{mL}^{-1}$.

Figures 1 and 2 show the kinetic curves of degradation of the DPPH radical by the different extracts at different concentrations of the castanholas. Each extract had a distinct behavior according to the concentration. The aqueous extract had a strong antioxidant capacity in the first five minutes of reaction with a significant reduction of DPPH radical. It was found that the higher the concentration of the extract, the higher the antioxidant activity in both the aqueous and alcoholic extract.

The efficiency of extraction of phenolic compounds with water was demonstrated once more by the fact that the aqueous extract, under the same conditions of concentration and reaction time of the alcoholic extract, changed the color of the DPPH to a greater extent, which shows that the antioxidant power of the aqueous extract is greater than the other extract and directly proportional to the quantity of extracted phenols.

When the same extraction conditions were used with fruits from the Brazilian Cerrado, such as murici and jenipapo, there was also a greater carrying efficiency of large amounts of hydrophylic phenols. As with the castanhola fruits, the ability to change the color of the DPPH radical is directly linked to the amount of total extracted phenols (MOREIRA-ARAUJO et al., 2010).

In the sample analyzed, the vitamin $\mathrm{C}$ content was not a determining factor in the high antioxidant potential of the fruit because of the low level of the vitamin $\left(0.22 \mathrm{mg} .100 \mathrm{~g}^{-1}\right)$.
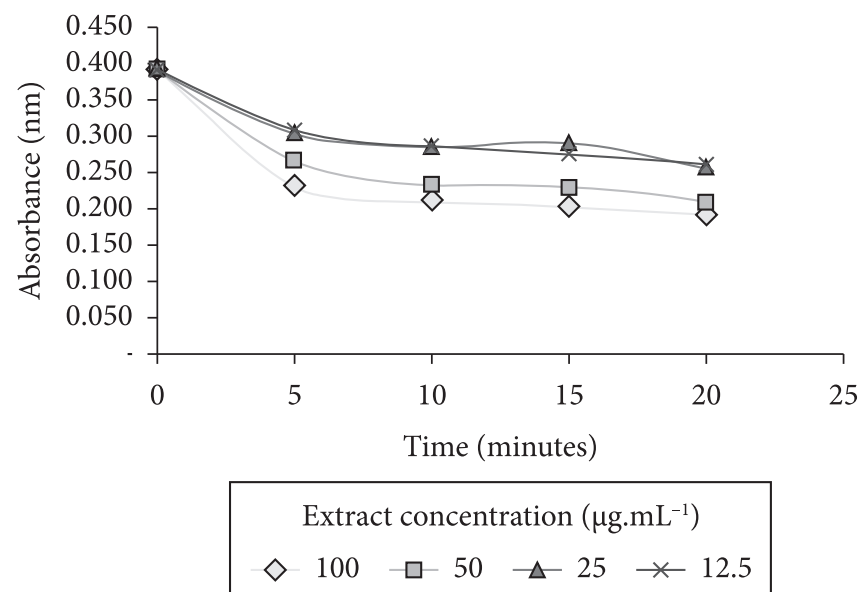

Figure 1. Kinetic curve of the antioxidant potential of the alcoholic extract of castanhola fruits using the DPPH assay. Teresina-PI, 2010.

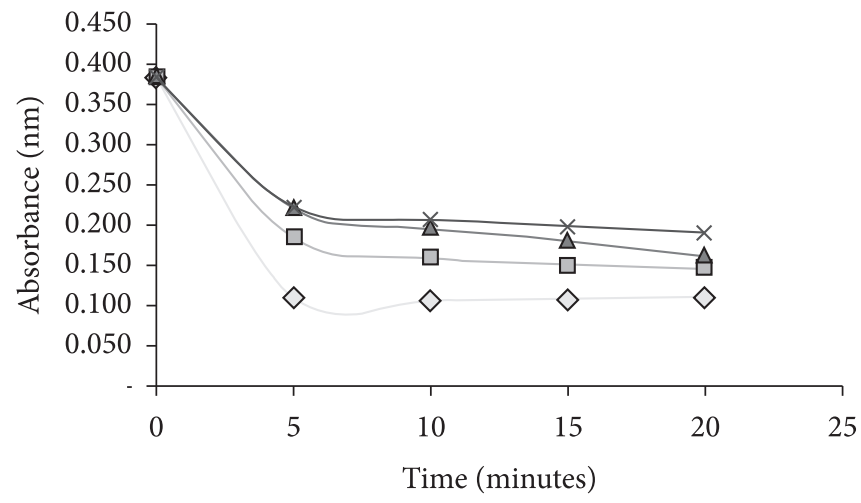

Extract concentration $\left(\mu \mathrm{g} \cdot \mathrm{mL}^{-1}\right)$

$\diamond 100 \quad \square 50 \rightarrow 25 \rightarrow 12.5$

Figure 2. Kinetic curve of the antioxidant potential of the aqueous extract of castanhola fruits using the DPPH assay. Teresina-PI, 2010.

\section{Conclusion}

It was concluded that although the castanhola fruit is not commercially exploited, it has a high calorific content and can be used as a source of carbohydrates, has a high pulp yield, and is a source of phenolic compounds with antioxidant properties that are comparable to the best known sources to date. This study showed that the majority of these compounds are hydrophilic and that water is the best solvent for extraction of castanhola. High levels of phenolic compounds extracted in aqueous media suggest high extraction efficiency in the human body during normal digestion since human body is composed mostly of water.

Further studies including other methodologies should be carried out to address the in vivo and in vitro antioxidant potential of this fruit and demonstrate its health benefits for humans.

\section{Acknowledgements}

This work was supported by CNPq, (Brazilian Research Funding Agency) Universal Edict 15/2007-Process 
No 481.333/2007-0. The author M. R. Marques would like to acknowledge his research fellowship granted by CNPq.

\section{References}

ABDILLE, M. D. H. et al. Antioxidant activity of the extracts from Dillenia indica fruits. Food Chemistry, v. 90, p. 891-896. 2005. http://dx.doi.org/10.1016/j.foodchem.2004.09.002

ANGEL, M. H. et al. Almendro de La índia: potencial biológico valioso. Revista Cubana Investigación Biomédica, v. 22, n. 1, p. 41-47. 2003.

ASOlINI, F. C.; TEDESCO, A. M.; CARPES, S. T.; Atividade antioxidante e antibacteriana dos compostos fenólicos dos extratos de plantas usadas como chás. Brazilian Journal of Food Technology, v. 9, n. 3, p. 209-215. 2006.

ASSOCIATION OF OFFICIAL ANALYTICAL CHEMISTS - AOAC. Official Methods of Analysis of AOAC International. 17. ed. AOAC, 2000. v. 2.

ATOUI, A. K. et al. Tea antioxidant activity and phenolic profile. Food Chemistry, v. 89, n. 1, p. 27, 2005. http://dx.doi.org/10.1016/j. foodchem.2004.01.075

BRAND-WILIAMS, W.; CUVELIER, M. E.; BERSET, C. Use of a free radical method to evaluate antioxidant activity. Food Science and Technology, v. 28, p. 25-30, 1995.

BROINIZI, P. R. B. et al. Evaluation of the Antioxidant Activity of Phenolic Compounds Naturally Contained in By-products of the Cashew Apple (Anacardium occidentale L.). Ciência e Tecnologia de Alimentos, v. 27, n. 4, p. 902-908. 2007. http://dx.doi. org/10.1590/S0101-20612007000400035

CAVALCANTE, M. A. et al. Características físicas químicas da Castanhola, Terminalia catappa L. Ciência Agronômica, v. 17, n. 1, p. 111-116. 1986.

GILMAN, E. F.; WATSON, D. G. Terminalia catappa tropicalalmond. Gainesville: Institute of Food and Agricultural Sciences, University of Florida, 1994.

INSTITUTO ADOLFO LUTZ - IAL. Métodos físico-químicos para análise de alimentos. São Paulo: IAL, 2008. 1020 p.

ISHIGE, K.; SCHUBERT, D.; SAGARA, Y. Flavonoids protect neuronal cells from oxidative stress by three distinct mechanisms. Free Rad Biology Medicine, v. 30, p. 433-466, AOAC 2001.

IVANI, S. A. et al. Morfologia de frutos, sementes e plântulas de castanheira. (Terminalia catappa L. - COMBRETACEAE). Revista Brasileira de Fruticultura de Jaboticabal, v. 30, n. 2, p. $517-$ 522. 2008. http://dx.doi.org/10.1590/S0100-29452008000200043

KATSUBE, N. et al. Induction of apoptosis in cancer cells by bilberry (Vaccinium mirtillus) and the anthocyanins. Journal Agriculture Food Chemistry, v. 51, p. 68-75. 2003. PMid:12502387. http:// dx.doi.org/10.1021/jf025781x

KHATOON, S. et al. Chemical Evaluation of Seven Terminalia Species and Quantification of Important polyphenols by TLC. Journal of Planar Chromatography, p. 167-171. 2008.

KIM, D.; JEONG, S. W.; LEE, C. Y. Antioxidant capacity of phenolic phytochemicals from various cultivars of plums. Food Chemistry, v. 81 , p. 321-326. 2003. http://dx.doi.org/10.1016/S03088146(02)00423-5

LARRAURI, J. A.; RUPÉREZ, P.; SAURA-CALIXTO, F. Effect of drying temperature on the stabilitity of polyphenols and antioxidant activity of red grape pomace peels. Journal Agriculture and Food Chemistry, v. 45, p. 1390-1393. 1997. http://dx.doi.org/10.1021/ jf960282f
LIMA, A. Caracterização química, avaliação da atividade antioxidante in vitro $e$ in vivo, e identificação dos compostos fenólicos presentes no Pequi (Caryocar brasiliense, Camb.) 2008. $182 \mathrm{f}$. Tese (Doutorado em Ciência dos Alimentos)-Faculdade de Ciência Farmacêuticas, Universidade de São Paulo, São Paulo, 2008.

MATOS, F. J. A. et al. Ácidos graxos de algumas oleaginosas tropicais em ocorrência no nordeste do Brasil. Química Nova, v. 15, p. 3. 1992.

MOREIRA-ARAUJO, R. S. R. et al. Determinação de fenólicos totais e atividade antioxidante de frutos do cerrado brasileiro. Conselho Nacional de Desenvolvimento Científico e Tecnológico CNPq, 2010. Relatório técnico (Edital Universal No 481.333/2007-0).

NAGAPPA, A. N. et al. Antidiabetic activity of Terminalia catappa Linn fruits. Journal of Ethnopharmacology, v. 88, p. 45-50. 2003. http://dx.doi.org/10.1016/S0378-8741(03)00208-3

OLIVEIRA, J. T. A. et al. Composition and nutritional properties of seeds from Pachira aquatic Aubl, Sterculia striata St Hil et Naud and Terminalia catappa Linn. Food Chemistry, v. 70, p. 185-191. 2000. http://dx.doi.org/10.1016/S0308-8146(00)00076-5

ROESLER, R. et al. Atividade antioxidante de frutas do cerrado. Ciência e Tecnologia de Alimentos, v. 27, n. 1, 2007. http://dx.doi. org/10.1590/S0101-20612007000100010

SÁNCHEZ-MORENO, C.; LARRAURI, J. A.; SAURA-CALIXTO, F. A procedure to measure the antiradical efficiency of polyphenols. Journal of the Science of Food and Agriculture, v. 76, p. 270-276. 1998. http://dx.doi.org/10.1002/(SICI)10970010(199802)76:2\%3C270::AID-JSFA945\%3E3.0.CO;2-9

SANTOS, G. M. Contribuição da vitamina C, carotenóides e compostos fenólicos no potencial antioxidante de produtos comerciais de açaí e cupuaçu. 2007. 99 f. Dissertação (Mestrado em Tecnologia de Alimentos)-Universidade Federal do Ceará, Fortaleza, 2007.

SHAHIDI, F.; ALASALVAR, C.; LIYANA-PATHIRANA, C. M. Antioxidant Phytochemicals in Hazelnut Kernel (Corylus avellana L.) and Hazelnut Byproducts. Journal Agriculture Food Chemistry, v. 55, n. 4, p. 1212-1220, 2007. PMid:17249682. http:// dx.doi.org/10.1021/jf062472o

SOARES, M. et al. Compostos fenólicos e atividade antioxidante da casca de uvas niágara e isabel. Revista Brasileira de Fruticultura de Jaboticabal, v. 30, n. 1, p. 59-64. 2008.

SOUSA, C. M. M. et al. Fenóis totais e atividade antioxidante de cinco plantas medicinais. Química Nova, v. 30, n. 2, 351-355. 2007. http:// dx.doi.org/10.1590/S0100-40422007000200021

STOCLET, J. C. et al. Vascular protection by dietary polyphenols. European Journal Pharmacology, v. 500, p. 299-313. 2004. PMid:15464042. http://dx.doi.org/10.1016/j.ejphar.2004.07.034

SWAIN, T.; HILLIS, W. E. The phenolic constituents of Prunus domestica. I. - The quantitative analysis of phenolic constituents. Journal of the Science of Food and Agriculture, v. 10, n. 1, p. 63 68, 1959. http://dx.doi.org/10.1002/jsfa.2740100110

THOMSON, L. A. J.; EVANS, B. Terminalia catappa (tropical almond), ver. 2.2. In: ELEVITCH, C.R. (Ed.). Species profiles for pacific Island agroforestry: permanent agriculture resources (PAR), 2006. Disponível em: <http://www.traditionaltree.org>

WANG, J.; MAZZA, G. Effects of anthocyanins and other phenolic compounds on the production of tumor necrosis factor alpha in LPS/IFN-gamma-activated RAW 264. 7 macrophages. Journal Agriculture Food Chemistry, v. 50, p. 4183-4189, 2002. PMid:12105943. http://dx.doi.org/10.1021/jf011613d 